\title{
Computerized nursing process: development of a mobile technology for use with neonates
}

\author{
Processo de enfermagem informatizado: construção de tecnologia móvel para uso em neonatos \\ Proceso de enfermería informatizado: construcción de tecnología móvil para uso en neonatos
}

\section{José Janailton de Lima', Larissa Gabrielle Dias Vieira", Marília Mendes Nunes"II}

'Escola de Saúde Pública do Ceará. Fortaleza, Ceará, Brazil.

"Centro Universitário Estácio do Ceará. Fortaleza, Ceará, Brazil.

"' Universidade Federal do Ceará. Fortaleza, Ceará, Brazil.

How to cite this article:

Lima JJ, Vieira LGD, Nunes MM. Computerized nursing process: development of a mobile

technology for use with neonates. Rev Bras Enferm [Internet]. 2018;71(Suppl 3):1273-80.

[Thematic Issue: Health of woman and child] DOI: http://dx.doi.org/10.1590/0034-7167-2017-0267

Submission: 05-08-2017 Approval: 07-21-2017

\begin{abstract}
Objective: to build a mobile technology to assist nurses during data collection, diagnostic reasoning, and identification of interventions in neonates. Method: methodological study with a qualitative approach. The development was carried out in three phases, namely: bibliographical survey, construction of a database of diagnosis/interventions, and development of the software. We used the development tools Ruby on Rails, IONIC 2, PostgresSQL, and Amazon EC2. Results: The developed technology received the name Natus, able to contribute to the development of the nursing process applied to patients of neonatal units. Its requirements are: to define human needs, select nursing diagnoses, select interventions, define time periods, and issue printed files. Final considerations: the technology built is a computerized tool that allows for the development of the nursing process, facilitating data collection, diagnostic reasoning, and identification and grouping of the clinical signs presented by the newborn in neonatal units.
\end{abstract}

Descriptors: Nursing Informatics; Information Technology; Neonatal Nursing; Biomedical Technology; Nursing.

\section{RESUMO}

Objetivo: construir uma tecnologia móvel para auxiliar o enfermeiro na coleta de dados, no raciocínio diagnóstico e na identificação de possíveis intervenções em neonatos. Método: estudo do tipo metodológico com abordagem qualitativa. A construção foi realizada em três fases: levantamento bibliográfico, montagem dos bancos de dados de diagnósticos/intervenções e desenvolvimento do software. As ferramentas de desenvolvimento utilizadas foram Ruby on Rails, IONIC 2, PostgresSQL e Amazon EC2. Resultados: A tecnologia elaborada recebeu o nome de Natus, capaz de contribuir para a elaboração do processo de enfermagem a pacientes de unidades neonatais. Tem como requisitos: definir as necessidades humanas, selecionar diagnósticos de enfermagem e intervenções, realizar aprazamentos e emitir impressos. Considerações finais: a tecnologia construída representa uma ferramenta informatizada que permite elaborar o processo de enfermagem e favorece a coleta de dados, o raciocínio diagnóstico, a identificação e o agrupamento dos sinais clínicos apresentados por recém-nascidos de unidades neonatais.

Descritores: Informática em Enfermagem; Tecnologia da Informação; Enfermagem Neonatal; Tecnologia Biomédica; Enfermagem.

\section{RESUMEN}

Objetivo: Construir una tecnología móvil para ayudar al enfermero en recolección de datos, razonamiento diagnóstico e identificación de intervenciones en neonatos. Método: Estudio de tipo metodológico, con abordaje cualitativo. La construcción se realizó en tres fases, a saber: relevamiento bibliográfico, montaje del banco de datos de diagnóstico/intervenciones y desarrollo del software. Las herramientas de desarrollo utilizadas fueron: Ruby on Rails, IONIC 2, PostgresSQL y Amazon EC2. Resultados: La tecnología elaborada, Ilamada Natus, es capaz de contribuir a elaborar el proceso de enfermería aplicado a pacientes de unidades neonatales. Sus requisitos son: definir las necesidades humanas, seleccionar los diagnósticos de enfermería, escoger las intervenciones, realizar aplazamientos y emitir una impresión. Consideraciones finales: La tecnología construida representa una herramienta informática 
que permite la elaboración del proceso de enfermería, facilitando recolección de datos, razonamiento diagnóstico, identificación y agrupación de los signos clínicos presentados por el recién nacido en unidades neonatales.

Descriptores: Informática Aplicada a la Enfermería; Tecnología de la Información; Enfermería Neonatal; Tecnología Biomédica; Enfermería.

\section{AUTOR CORRESPONDIENTE José Janailton de Lima E-mail: jjanailtim@gmail.com}

\section{INTRODUCTION}

The meaning of the term Technology is the merger between theoretical (scientific and technical) and practical knowledge applied to the development of tools, materials and processes that, once used, allow the resolution of problems. Thus, medical technology is any tool that can be used to promote health. This concept includes not only technologies that interact directly with patients, such as medicines, equipment (biomedical technologies), and procedures such as anamnesis, surgical techniques, and technical norms for equipment usage, but also organizational and support systems within which health care is offered ${ }^{(1)}$.

Information Technologies (IT) are widely used in the field of health care, with informatics being a resource increasingly present in the environment of care. Nursing Informatics is the area of knowledge that studies the applicability of technological resources concerning practicality, care, and assistance and care management, having as purpose the improvement of patient care and a more humanized work ${ }^{(2)}$. It is a specialty that involves the science of nursing, computer science, and information science, which has been applied and developed for over 35 years, potentializing research, teaching, and praxis in nursing, with the aim of promoting systemic, fast, and good care ${ }^{(3)}$.

Nursing, because of its relationship with health and as a profession directly involved in human care, cannot be apart from the transformations of technological development. Exploring the potential of these changes and recognizing their possibilities is essential for the professionals' awareness of the increasing use of computational technology $y^{(4)}$.

It is possible to observe computer technology applied in health care, by the presence of electronic equipment at the head of beds, monitoring and controlling the patient's condition. As nursing professionals are present 24 hours a day directly involved in patient care, it is important to consider computer technology as a tool capable of optimizing the availability of nurses concerning assistance and managerial activities.

The use of IT for human care in nursing can be seen as something challenging and innovative, and in the nursing scenario, it is possible to perceive some resistance from some professionals to appropriate technologies and subsequent use as tools for integration among the various dimensions of care ${ }^{(5)}$.

Currently, nurses have one important challenge: to provide patients with safe and high-quality care, considering the volume of still disrupted and disintegrated information that involve care, in addition to the numerous time demands for appropriate clinical assessment.

In this context, the application of technological resources can bring advantages and improvements in the performance and work of nurses, specifically aimed at increasing the professionals' available time for activities related to care. The benefit of technological tools for health assistance has been elucidated in the literature in the context of medical practice, from the comparison of time devoted by professionals to record by hand or by typing on a computer program ${ }^{(6)}$.

This study proposes the use of information technology as a useful tool for nursing care, including all records and enabling nurses to optimize patient-centered assistance time and maximizing the quality of the service, in addition to facilitating communication among team members.

Nursing, as the largest group working in health institutions, should consider reshaping its work processes with the use of computer tools. However, it is important to evaluate the actual and potential benefits that these resources can bring to the work involved in the Nursing Process (NP) and its proper documentation on the Systematization of Nursing Assistance (SNA), since many flaws of record occur in the traditional method.

SNA was essentially thought to improve the organization of work and documentation processes. Its mandatory implementation is recommended by Resolution no. 358 of the National Board of Nursing, which set out the steps and way of registering data in medical records ${ }^{(7)}$.

The concepts of NP and SNA have distinct meanings, even though they are used in parallel in the realization of care, which leads to misunderstanding. NP is the methodological, scientific instrument used to facilitate the provision of quality care, centered on the individual, family, or collective entity. It is assumed that nurses perform intellectual work consisting of five phases or stages, which are interconnected, interdependent, and recurrent in accordance with Resolution no. 358/2009, namely: Nursing Historic, Nursing Diagnosis, Nursing Planning, and Nursing Implementation and Evaluation $^{(7)}$. Those stages should be based on a theoretical support that guide their development. SNA enables the organization of work and the operationalization of NP by nursing professionals, giving autonomy to the professional practice.

In clinical practice, a high time to prepare SNA can be observed in neonatal units daily, which can reduce the time of much-needed care to this fragile clientele.

According to the health situation, the newborn or neonate (child aged from 0 to 28 days) may require special care in the NICU (Neonatal Intensive Care Unit), CINCU (Conventional Intermediate Neonatal Care Unit) or KINCU (Kangaroo Intermediate Neonatal Care Unit) ${ }^{(8)}$, with periods of hospitalization ranging from hours to months. During this period, this child should be surrounded by nursing teams that will assist him/ her, requiring extensive knowledge from these professionals in the development of care plans, as well as hours of direct assistance to better meet the health needs of newborns. 
Recognizing the importance of a computational tool that provides greater availability of nurses for assistance activities, it is possible to verify the need to seek, within information technology, a new way to perform and register the Nursing Process, providing a computerized, individualized, fast, and efficient register for each client. Thus, we believe that a software developed considering the specific characteristics of a clientele can optimize the development of a care plan, when compared to a more comprehensive software.

\section{OBJECTIVE}

To construct a mobile technology capable of assisting the nurse in performing nursing prescription in neonate patients.

\section{METHOD}

\section{Ethical aspects}

In this phase of development of the mobile technology, permissions were requested from the international publishers for use of taxonomies NANDA International, Inc. (NANDA-I) and NIC (Nursing Interventions Classification). The scientific articles selected for the creation of the databases had their authors mentioned and all ethical principles were respected.

\section{Theoretical-methodological background}

\section{Applied Nursing Theory}

In nursing, theories are defined as the conceptualization of a reality, with the purpose of understanding and describing its phenomena, explain the relationships between them, predict consequences, and prescribe nursing care ${ }^{(9)}$. Theories should consider the creative development of individuals, families, and collective entities, in their different aspects, to then find a satisfactory and effective care. It must direct the actions of nurses, allowing the care provided not to be carried out in an empirical way ${ }^{(10)}$.

Nursing theories contain elements that represent the core of this discipline: nursing, the person, the environment and health, called nursing metaparadigms. These elements illustrate who is the target public to this care, what is the purpose of nursing care, in what environment will it be developed and how it should be performed.

To choose a nursing theory to substantiate their practice, nurses need to know the reality of the sector they work in, the profile of nurses who work in the unit, and the clientele served, since this characterization should be in accordance with the concepts of the selected theory. The theory works as the structural foundation for the establishment of SNA, therefore, it is the conceptual framework supporting the organization of nursing care ${ }^{(10)}$.

As framework for the development of the mobile technology, we opted for the use of Basic Human Needs Theory, proposed by Wanda de Aguiar Horta, since the neonate clientele is totally dependent on the care. In addition, psychobiological needs are intrinsic to every human being from the moment of birth. Psychosocial needs are linked to the physical and emotional development of the newborn, through the establishment of human relations and bonds with the caregiver (family health team and family) ${ }^{(11)}$.

\section{Nursing Classification systems incorporated into the mo- bile technology}

Among the existing classification systems, we decided to use the taxonomy of NANDA International, Inc. (NANDA-I) for the survey of nursing diagnoses, since it its widely used in the neonatology services registered in the literature. In the selection of nursing interventions, the Nursing Interventions Classification (NIC) was employed. This taxonomy has association with the NANDA-I in the pursuit for standardization of the language of nursing practice.

\section{Type of study}

This is a methodological study with qualitative approach. Methodological research develops instruments and usually involves complex and sophisticated methods. It is the investigation of the methods for obtaining and organizing data and conducting of rigorous research. Methodological studies deal with development, validation, and evaluation of research tools and methods ${ }^{(12)}$.

When performing a methodological study, the researcher's goal is the development of a reliable, accurate, and usable tool that can be used by other researchers. This type of study fits any scientific discipline, dealing with complex phenomena such as the behavior or health of individuals, as occurs in nursing research ${ }^{(13)}$.

The qualitative approach assumes the grounds that there is a dynamic relationship between the real world and the individual, in which knowledge cannot be reduced to a list of isolated data, connected by an explanatory theory. In this context, the individual-observer is an integral part of the process of knowledge production and interpret the phenomena by assigning them a meaning ${ }^{(14)}$.

\section{Methodological procedures}

The development of the mobile technology was carried out in three phases, namely: bibliographical survey, construction of a data base, and development of the software.

\section{Step 1: Bibliographic Survey}

The survey was conducted looking for theoretical explanations and/or scientific articles on themes related to nursing diagnosis found in neonatal units. For this, we identified in DeCS (Health Sciences Descriptors), the existing terms that were suitable to our search. The terms selected were: neonatal nursing, maternal-child nursing, nursing diagnosis, pediatric nursing, nursing care, and nursing processes (all in Portuguese).

The terms were combined, and the search took place in September 2016, restricting the period range from 2005 to 2015, with full text available in Portuguese. We used the site of the BVS (Brazilian Virtual Health Library), for bringing together a "network of networks" for sharing and indexing of scientific papers. Articles that did not present nursing diagnosis in neonatal units and that were not published in the period referred to above were excluded. After being analyzed, five articles were selected, for being better suited to the purpose of this study and presenting significant relevance for the study. Among the authors of these articles are: Santos et al. ${ }^{(15)}$, 
Oliveira, Souza and Silva(16), Neves, Araújo and Lacerda ${ }^{(17)}$, Urakawa and Kobayashi ${ }^{(18)}$, and Del'Angelo et al. ${ }^{(19)}$.

\section{Step 2: Construction of Databases}

In possession of the scientific articles, all nursing diagnoses present were listed, excluding the ones that were repeated or nonexistent in NANDA-I (2015-2017). Thus, 36 nursing diagnoses were listed for the first database, using the software Exce ${ }^{\circledR}$ to allow a better visualization of the components of the diagnoses and facilitate their organization within the Basic Human Needs Theory.

To this end, ten columns were established, titled: Levels, Basic Human Needs, Definition, Empirical Needs, Problemfocused Nursing Diagnosis, Risk Nursing Diagnosis, Health Promotion Nursing Diagnosis, Defining Characteristics, Related Factors, and Risk Factors.

The levels refer to the theory by João Mohana on Human Motivation (1978), in which he classifies the human needs in three levels: Psychobiological Needs, Psychosocial Needs, and Psychospiritual Needs ${ }^{(14)}$.

Basic Human Needs are defined by Horta (1979) as states of tensions, conscious or unconscious, resulting from homeodynamic imbalances of vital phenomena, those conditions or situations that the individual, family, and community present due to the imbalance and that require a resolution ${ }^{(20)}$. Based on this concept, the selected diagnoses were allocated on the needs involved, with ten psychobiological needs and two psychosocial ones.

The term Definition is presented as the meaning of each basic human needs, according to Wanda Horta. The Empirical Needs in the hierarchy of nursing knowledge are the criteria and/or experimental conditions used to observe or measure the concepts of a theory. In this study, the empirical needs were considered as observed manifestations of basic human needs affected in the neonatal client, in other words, the physical examination ${ }^{(21)}$.

A nursing diagnosis can be targeted to a problem, a state of health promotion or of risk. We understand as Problemfocused Nursing Diagnosis the clinical judgement on an undesirable human response to an existing health/vital condition in an individual, family, or community ${ }^{(22)}$.

We have a Risk Nursing Diagnosis when the clinical judgement is made based on the vulnerability of the individual, family, or community to develop a desirable response to health conditions/life processes ${ }^{(22)}$.

Health Promotion Diagnoses are present when there is clinical judgement about the motivation to increase well-being and achieve human health potential ${ }^{(22)}$.

Defining Characteristics are observable and reported indicators (signs and symptoms) that are grouped as manifestations of a problem-focused diagnosis, which the nurse obtains after investigation or assessment, allowing him/her to identify the diagnosis ${ }^{(23)}$.

Related Factors are causative or etiologic factors and appear to show a standardized relationship with nursing diagnosis, guiding nursing interventions ${ }^{(22)}$.

Risk Factors represent environmental factors and physiological, psychological, genetic, or chemical elements that increase the vulnerability of an individual, family, or community to an unhealthy event ${ }^{(23)}$.

Database 2 was developed separately for the researchers' convenience in Word $^{\circledR}$ and aimed to facilitate the visualization of the nursing activities selected for each diagnosis and the use by the development team of the software, containing two columns, titled Nursing Diagnosis and Nursing Interventions, showing the definition of the intervention chosen and, below, a list with the nursing activities. The interventions were listed from each nursing diagnosis, with the aid of the NIC taxonomy. The construction of this database enabled the insertion of data and their structure into the software.

A Nursing Intervention is any treatment based on a clinical judgment made by a nurse to improve patient outcomes. Activities are the actions performed by the nurse to solve the presented problems ${ }^{(24)}$.

\section{Step 3: Software development}

The development of the technology was operationalized through the waterfall model or classic life cycle, proposed by Winston Royce. This model suggests a sequential and systematic approach, in which the software requirements were well understood by the proposer and the development team obeyed well defined steps during the process, as noted below $^{(25)}$ (Figure 1).
Communication

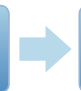

Planning

Modeling

Development
Figure 1 - Steps of development of a software proposed by Pressman \& Maxim (2016)

The phases were implemented as follows:

- Communication: survey of the application's needs, with definition of general objectives, being listed the requirements to be offered by the software.

- Planning: permeated by frequent contact with the development team, to estimate costs and details to be observed in the following steps, with two face-to-face meetings and eight meetings via webcam.

- Modeling: the requirements were analyzed, being defined the interface and the support base for application's operation. The application was developed in 32 working days, to work in test mode on a tablet, with the Android ${ }^{\circledR}$ operating system installed, chosen due to its mobility, handling, storage capacity, and ease of access by the touch of fingers.

- Development: comprised the coding and testing, with the use of development languages (Ruby on Rails, IONIC 2, PostgresSQL, and Amazon EC2) and a period of detection and correction of problems in the implementation and operation of the software. The correction period was critical, with multiple corrections to be made, thus requiring more 15 working days for the necessary improvements. 


\section{RESULTS}

We named the developed technology Natus, which is a Latin word meaning born, thus associating the target audience for the use of the application and because it is something new, freshly created. Initially, only one mobile device had the application installed, since it is a new project, which still require adjustments. To work properly, internet access is also required. It is important to highlight that the process for the registration of this technology will be started from the new version, after the specific quality studies have been carried out.

A requirement is a necessary condition for the user to solve a problem or achieve a goal. For a software, it is the ability that must be achieved or possessed by a system or component to satisfy a contract, known as functionality ${ }^{(26)}$.

The set of functionalities required for the application's performance was: list the patients, add a new patient, view and search patients, define the needs (Psychobiological or Psychosocial), search and send empirical needs, search and send diagnoses, perform a preliminary selection of the most prevalent diagnoses, search and send defining characteristics, search and send selected factors, search and send interventions, search SNA, and generate PDF files.

The functions are presented to the user through an initial menu with two options: new patient and registered patient, allowing nursing admission and searching the list of existing patients.

When selecting the "new patient" option, the user is directed to the completion of essential information about the newborn, such as: mother's name, date and time of birth, gestational age (GA) in weeks and days, and life-time in days and hours. The system sorts the patients through GA (Figure 2).

After the registration of the newborn, a menu of options appears, in which the user can select between viewing a rapid history of admission, showing the previous NP, or choosing to develop a new one. If the patient already has other NP, the user can access them by the date and print the information. If the patient is registered, the system will lead the user to the list of patients. When selecting the patient, the nurse is directed to the options menu, which allows him/her to achieve the desired item faster. In the "New NP" (Figure 2) option, the nurse is directed to the screen of human needs to select the specific need of the newborn (Figure 3).

If choosing Psychobiological Needs, the user will be directed to select the needs to be observed and listed based on Gouvea's study on development and validation of an instrument for data collection on newborns in Neonate Intensive Care Units (NICU) ${ }^{(14)}$. Selecting "Psychosocial Needs", the options for this need will also be displayed. If there are doubts, the nurse can check the definition of every need, ensuring greater security regarding clinical reasoning.
After the selection of the empirical needs, the application will present a list of possible pre-built nursing diagnoses, for nurses to select those which they consider priorities (Figure 3).

After the selection of priority diagnoses, the application will lead to the related factors screen for each nursing diagnosis previously chosen so that the nurse, using clinical reasoning, can affirm which related factors are contributing to the existence of those diagnoses (Figure 4).

With this moment done, the nursing diagnoses are presented according NANDA-I guidance, having stated diagnoses, defining characteristics, and related factors either if they are real or only enunciated, and related factors if they are of risk. Those that were not considered by the user's assessment may be excluded.

Upon selection, the system will show the screen of desired interventions for diagnoses. According to the indicated action, a screen will appear with the possibility of setting a period for a determined action with start time and repeat interval, to assist in the gain of time after issuance of the NP sheets. The action that has been selected and its time periods decided will be marked with a different color to facilitate understanding that those steps have already been carried out (Figure 3).

After completion of the interventions to be desired for the newborn, the nurse will complete the process with the issuance of the NP sheet if desired, downloading the file in Portable Document Format (PDF) for printing. There is also an option to use it on a paper record, if necessary (Figures 4 and 5).

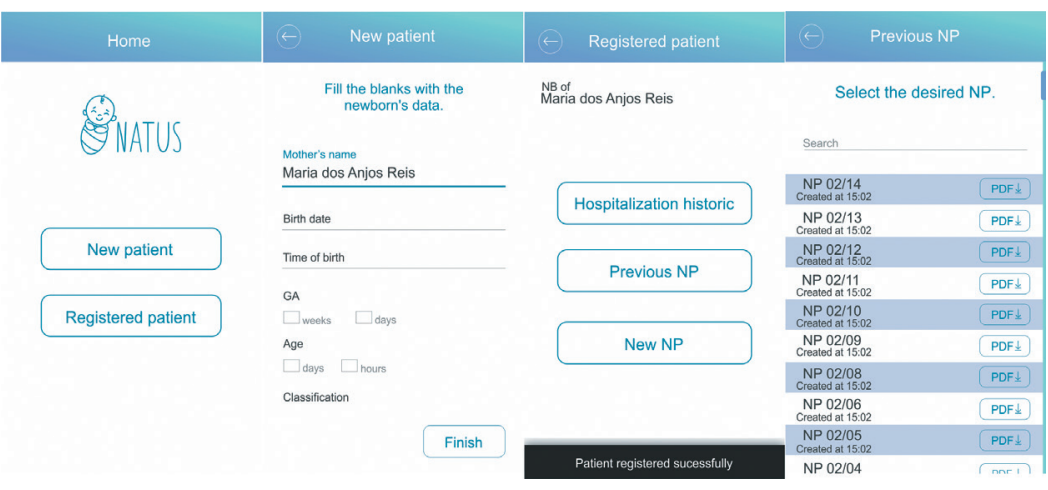

Figure 2 - Initial menu screens, initial data, options menu for registered patients, and earlier patients' Nursing Process, respectively

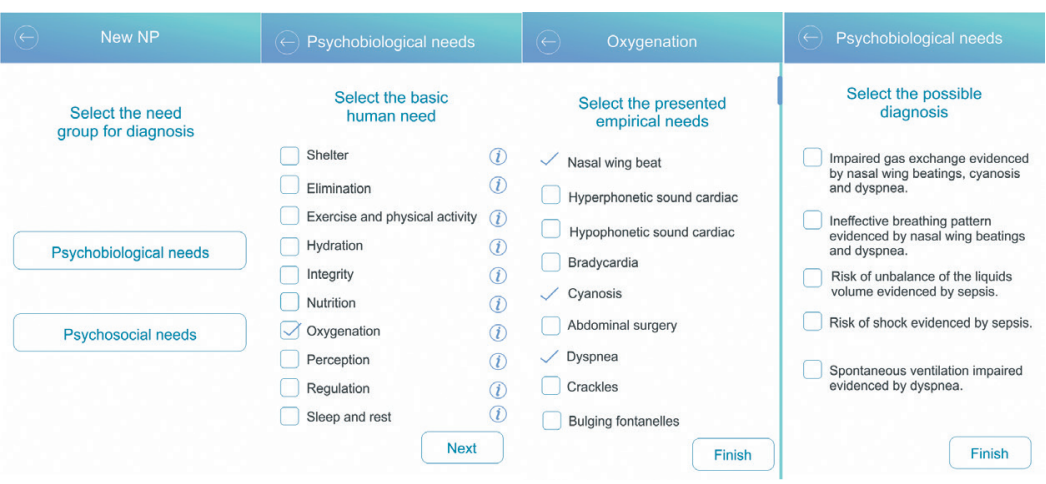

Figure 3 - Needs group screens, psychobiological human needs, list of empirical needs for selection, and possible diagnoses issued 


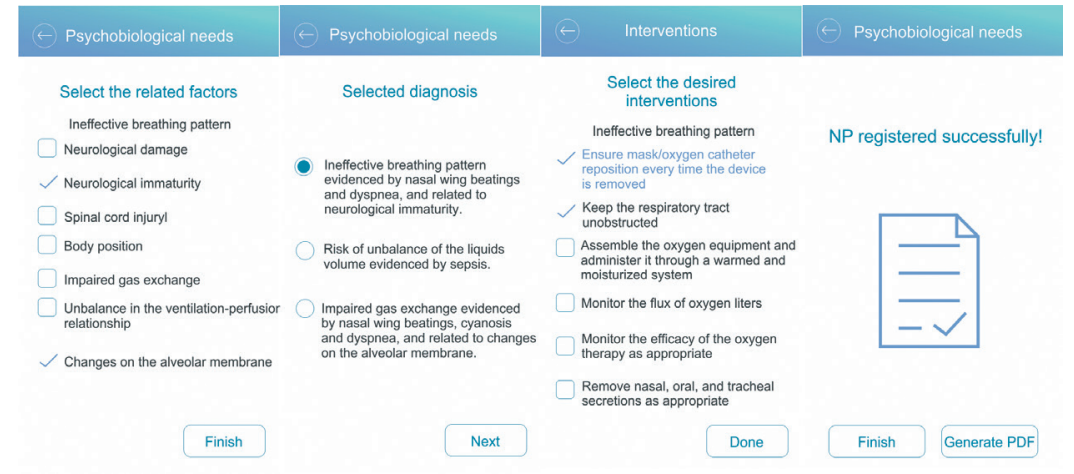

Figure 4 - Related factors screen, selected diagnosis, list of desired interventions, and completion of the Nursing Process registration, respectively

\begin{tabular}{|c|c|c|c|c|}
\hline \multicolumn{5}{|c|}{$\begin{array}{c}\text { SYSTEMATIZATION OF NURSING ASSISTANCE } \\
\text { NURSING PRESCRIPTION }\end{array}$} \\
\hline \multicolumn{2}{|c|}{ NB of Maria dos Anjos Reis } & Date: 01/12/2017 & \multicolumn{2}{|c|}{ Unit: NICU } \\
\hline $\begin{array}{l}\text { NURSING } \\
\text { DIAGNOSIS }\end{array}$ & INT & $\begin{array}{l}\text { NURSING } \\
\text { ERVENTIONS }\end{array}$ & TIME PERIOD & NOTES \\
\hline $\begin{array}{l}\text { Risk of unbalance of } \\
\text { body temperature, } \\
\text { evidenced by sepsis, } \\
\text { weight extremes }\end{array}$ & $\begin{array}{l}\text { Monit } \\
\text { tempe } \\
\text { the ne } \\
\text { Keep t } \\
\text { body } \\
\text { Put an } \\
\text { avoid }\end{array}$ & $\begin{array}{l}\text { rature of } \\
\text { wborn. } \\
\text { he newborn's } \\
\text { varm. } \\
\text { elastic cap to } \\
\text { heat loss. }\end{array}$ & $\begin{array}{c}8 \mathrm{~h} 14 \mathrm{~h} 20 \mathrm{~h} 2 \mathrm{~h} \\
14 \mathrm{~h}\end{array}$ & \\
\hline $\begin{array}{l}\text { Ineffective airway } \\
\text { clearance } \\
\text { evidenced by } \\
\text { dyspnea, related } \\
\text { to excessive mucus }\end{array}$ & $\begin{array}{l}\text { Detern } \\
\text { oral an } \\
\text { aspirat } \\
\text { Aspirat } \\
\text { tract in } \\
\text { Listen } \\
\text { sounds } \\
\text { aspirat }\end{array}$ & $\begin{array}{l}\text { ine the need for } \\
\text { d/or endotracheal } \\
\text { on. } \\
\text { e the respiratory } \\
\text { mediately. } \\
\text { o the respiratory } \\
\text { before and after } \\
\text { on. }\end{array}$ & $07 \mathrm{~h} 30$ & \\
\hline $\begin{array}{l}\text { Nurse } \\
\text { COREN No }\end{array}$ & & & & \\
\hline
\end{tabular}

Figure 5 - Printed sheet for paper record

\section{DISCUSSION}

The development of mobile devices can represent a viable solution for the health sector, since we are facing a scenario in the digital age, in which the adoption of technologies for care provide higher case management, fast and safe assessment of clients, management and storage of data.

In a study on the use of mobile technology for the clinical evaluation of newborns, it was observed that the advantages in the use of this technology are focused on mobility and agility to perform the documentation of information, thus optimizing the time, promoting greater flexibility in the management of care actions by using a tablet, as the records can thus be made beside the patient's bed $^{(27)}$.
A satisfactory result was found by Schachner et al. (2016) when evaluating the use of a mobile device by the nursing staff of a hospital of Buenos Aires, Argentina. The users considered the tablet a useful tool, assisting them in the implementation of tasks in real time in a faster way, thus facilitating the work flow, allowing more accurate and dynamic records ${ }^{(28)}$.

Another study conducted with nurses from two hospitals in the state of Santa Catarina, Brazil, regarding the use of mobile devices revealed that the system presented practical application by allowing nurses to assess, intervene, and manage nursing care, providing greater security and involvement of nurses with the needs of the client at their bedside ${ }^{(29)}$.

It seems that the development of software for the planning of care tend to enable nurses to use the content present in these materials to help them apply or modify the clinical judgement, support decision-making in the diagnoses selection process and nursing interventions, in addition to being a learning tool capable of broadening the knowledge of professionals, as was well documented in the works by TingTing (2006) and Silva (2015) ${ }^{(30-31)}$.

Not only for nursing, but other areas also have shown interest in developing mobile applications, with the goal of facilitating the access of professionals' to patients' conditions, optimizing their activities, and assisting in communication among professionals ${ }^{(32)}$.

Although there are reports of the development of other health mobile devices, it is still a small but potentially growing field that has drawn the attention of researchers to the importance of developing new technologies tested in research and implemented in practice ${ }^{(27,32)}$.

\section{Study limitations}

As limitations of this study, we point out the reduced space for incorporation of screens for using the assessment scales for the implemented care prescribed, through the NOC taxonomy, as well as the high financial cost of development. It is important to highlight that this technology will be tested by nurses working in neonatal units and will undergo adjustments in future validation studies.

Contributions to the field of nursing, health, or public policies

The development of the mobile application is shown as a viable solution to nursing work performance, considering that SNA is used by all professionals in the field. Thus, this tool can provide greater problem-solving capacity, theoretical foundation allied to the practice and give more time for the nurse who elaborates the SNA, as well as greater understanding of the interventions by technicians and nursing 
assistants who use it as a guide for care. In short, it may contribute to improve the treatment offered to hospitalized neonates.

\section{FINAL CONSIDERATIONS}

The creation of the Natus technology allowed the expansion of tools for application of the Nursing process in neonatal units. The application is an objective and clear tool that allows nurses to systematize the nursing care, facilitating data collection with pooling of clinical signs, and assisting in the identification of diagnoses and selection of nursing interventions for neonates. However, it is necessary to know the clinical indicators, as well as the accurate methods for the correct measurement of these indicators by the professional.

This technology does not intend to exclude the clinical judgement and diagnostic reasoning of the nurse, since, for the professional to use it, previous scientific knowledge is demanded.

Natus intends to contribute so that the nurse can perform the nursing process, based on nursing theories, offering care based on scientific evidence, enabling the nurse to perform part of the process of carrying out nursing systematization. We understand that, for the application to be implemented in the practical care field, it will be necessary to carry out the second phase of this study, which consists in validating the application. After this step, the application will be made available by the authors, through release of license for proper use.

\section{REFERENCES}

1. Brasil. Ministério da Saúde. Avaliação de tecnologias em saúde: ferramentas para a gestão do SUS. Brasília: MS; 2009.

2. Palomares MLE, Marques IR. Contribuições dos sistemas computacionais na implantação da sistematização da assistência de enfermagem. J Health Inform [Internet]. 2010 [cited 2017 Apr 11];3(2):78-82. Available from: http://www.jhi-sbis.saude.ws/ojs-jhi/ index.php/jhi-sbis/article/view/94/34

3. Melo ECA, Enders BC. Construção de sistemas de informação para o processo de enfermagem: uma revisão integrativa. J Health Inform[Internet]. 2013[cited 2017 Apr 11];1(5):23-29. Available from: http://www.jhi-sbis.saude.ws/ojs-jhi/index.php/jhi-sbis/ article/view/233/161

4. Sperandio DJ, Évora YDM. Sistematização da assistência de enfermagem: uma proposta de software-protótipo. Esc Anna Nery Rev Enferm[Internet]. 2003 [cited 2017 Feb 8];7(2):269-82. Available from: http://www.scielo.br/pdf/rlae/v13n6/v13n6a04.pdf

5. Baggio MA, Erdmann AL, Sasso GTM. Cuidado humano e tecnologia na enfermagem contemporânea e complexa. Texto Contexto Enferm[Internet]. 2010 [cited 2017 Apr 06];2(19):54-63. Available from: http://www.redalyc.org/pdf/714/71416097021.pdf

6. Shu K, Boyle D, Spurr C, Horsky J, Heiman H, O'Connor P, et al. Comparison of time spent writing orders on paper with computerized physician order entry. In: Patel VL, Rogers R, Haux R, (Eds.). Studies in Health Technology and Informatics. Amsterdam, Netherlands, IOS Press BV MEDINFO; 2001 p. 1207-11.

7. Conselho Federal de Enfermagem - Cofen. Resolução COFEN-358/2009. [Internet]. 2009 [cited 2017 Apr 11]. Available from: http://www.cofen.gov.br/resoluo-cofen-3582009 4384.html

8. Brasil. Ministério da Saúde. Portaria n 930, de 10 de maio de 2012.[Internet]. 2017 [cited 2017 Apr 11 ]. Available from: http:// bvsms.saude.gov.br/bvs/saudelegis/gm/2012/prt0930 1005 2012.html

9. Meleis Al. Theoretical nursing: development \& progress. 5 ed. Philadelphia: Lippincott Willians \& Wilkins, 2012.

10. Tannure MC, Pinheiro AM. SAE Sistematização da assistência de enfermagem: guia prático. 2 ed. Rio de Janeiro: Guanabara Koogan; 2010.

11. Gouvea JA. Construção e validação de um instrumento de coleta de dados para recém-nascidos internados na unidade de terapia intensiva neonatal do Hospital Universitário Lauro Wanderley [Dissertação]. Universidade Federal da Paraíba; 2007.

12. Polit DF, Beck CT. Fundamentos de pesquisa em enfermagem: avaliação de evidências para as práticas da enfermagem. 7 ed. Porto Alegre: Artmed; 2011.

13. Polit DF, Beck CT, Hungler BP. Fundamentos de pesquisa em enfermagem: métodos, avaliação e utilização. 5 ed. Porto Alegre: Artmed; 2004.

14. Chizzotti A. Pesquisa em ciências humanas e sociais. São Paulo: Cortez; 2009.

15. Santos APS, Silva MLC, Souza NL, Mota GM, França DF. Nursing diagnoses of newborns with sepsis in a Neonatal Intensive Care Unit. Rev Latino-Am Enfermagem[Internet]. 2014 [cited 2017 Apr 11];22(2):255-61. Available from: http://www.scielo.br/pdf/rlae/ v22n2/0104-1169-rlae-22-02-00255.pdf

16. Oliveira SIM, Souza NL, Silva RKC. Diagnósticos de enfermagem em recém-nascido com alterações glicêmicas. Cogitare Enferm[Internet]. 2013 [cited 2017 Apr 11];18(4):702-8. Available from: http://revistas.ufpr.br/cogitare/article/view/34923/21677

17. Neves RS, Araújo PHM, Lacerda TCL. Diagnósticos de enfermagem prevalentes no bloco materno-infantil de um hospital público de Brasília. Enferm Foco[Internet]. 2014 [cited 2017 Apr 11];5(3/4):53-6. Available from: http://revista.portalcofen.gov.br/index. php/enfermagem/article/view/560/242 
18. Urakawa IT, Kobayashi RM. Identificação do perfil e diagnósticos de enfermagem do neonato com cardiopatia congênita. Rev Pesq: Cuid Fundam[Internet]. 2012 [cited 2017 Apr 09];4(4):3118-24. Available from: http://www.seer.unirio.br/index.php/ cuidadofundamental/article/view/1898/pdf_669

19. Del'Angelo N, Góes FSN, Dalri MCB, Leite AM, Furtado MCC, Scochi CGS. Diagnósticos de enfermagem de prematuros sob cuidados intermediários. Rev Bras Enferm [Internet]. 2010 [cited 2017 Apr 09];63(5):755-61. Available from: http://www.scielo. br/pdf/reben/v63n5/10.pdf

20. Horta WA. Processo de enfermagem. São Paulo: EPU; 1979.

21. Souza A, Soares M, Nóbrega M. Indicadores empíricos para a estruturação de um instrumento de coleta de dados em unidade cirúrgica. Rev Eletr Enf [Internet]. 2009 [cited 2017 Apr 12];11(3):501-8. Available from: https://www.fen.ufg.br/fen_revista/v11/ $\mathrm{n} 3 / \mathrm{pdf} / \mathrm{v} 11 \mathrm{n} 3 \mathrm{a} 06 . \mathrm{pdf}$

22. Herdman TH, Kamitsuru S, (Eds.). Diagnósticos de enfermagem da NANDA: definições e classificação 2015-2017. Porto Alegre: Artmed; 2015.

23. Herdman TH. Diagnósticos de enfermagem e sua relação com o raciocínio clínico. In: Herdman TH, (Org.). PRONANDA Programa de Atualização em Diagnósticos de Enfermagem: conceitos básicos. Porto Alegre: Artmed Panamericana; 2013. p. 29-63. (Sistema de Educação Continuada a Distância).

24. Bulechek GM, Butcher H, Dochterman JM. Classificação das Intervenções de Enfermagem (NIC). Rio de Janeiro: Elsevier, 2011.

25. Pressman RS, Maxim BR. Engenharia de Software: uma abordagem profissional. 8 ed. Amgh Editora; 2016.

26. Sousa VEC. Modelos computacionais de desenvolvimento de softwares para o ensino de diagnósticos de enfermagem. In: Herdman TH, (Org.). PRONANDA - Programa de Atualização em Diagnósticos de Enfermagem. Porto Alegre: Artmed Panamericana; 2014. p. 33-69. (Ciclo 2).

27. Rezende LCM. Mobile technology for recording the clinical assessment of newborns. Cogitare Enferm [Internet]. 2016 [cited 2017 Apr 11];21(1):1-7. Available from: http://revistas.ufpr.br/cogitare/article/view/42868/27633

28. Schachner MB, Sommer JA, González ZA, Luna DR, Benítez SE. Evaluating the feasibility of using mobile devices for nurse documentation. In: Sermeus W, Procter PM, Webe P, (Eds.). 13th International Congress in Nursing Informatics, 2016 Jun 25-29, Geneva, Switzerland. IOS Press BV, Amsterdam, Netherlands, p.495-9.

29. Barra MA, Sasso GTM. Tecnologia móvel à beira do leito: processo de enfermagem informatizado em terapia intensiva a partir da CIPE 1.0. Texto Contexto Enferm [Internet]. 2010 [cited 2017 Apr 11];19(1):54-63. Available from: http://www.scielo.br/pdf/tce/ v19n1/v19n1a06.pdf

30. Ting-Ting L. Nurses' perceptions of their documentation experiences in a computerized nursing care planning system. J Clin Nurs[Internet]. 2006 [cited 2017 Jun 22];15(11):1376-82. Available from: http://onlinelibrary.wiley.com/doi/10.1111/j.1365-2702.2006.01480.x/full

31. Silva KL, Évora YDM, Cintra CSJ. Software development to support decision making in the selection of nursing diagnoses and interventions for children and adolescents. Rev Latino-Am Enfermagem [Internet]. 2015 [cited 2017 Jun 22];23(5):927-35. Available from: http://www.scielo.br/pdf/rlae/v23n5/0104-1169-rlae-23-05-00927.pdf

32. Tibes CMS, Dias JD, Zem-Mascarenhas SH. Mobile applications developed for the health sector in Brazil: an integrative literature review. Rev Min Enferm [Internet]. 2014 [cited 2017 Apr 11];18(2):471-8. Available from: http://www.reme.org.br/artigo/detalhes/940 